\title{
After Race and Class: Recent Trends in the Historiography of Early Colonial Cape Society
}

\section{Nigel Worden}

To cite this article: Nigel Worden (2010) After Race and Class: Recent Trends in the Historiography of Early Colonial Cape Society, South African Historical Journal, 62:3, 589-602, DOI: $10.1080 / 02582473.2010 .519904$

To link to this article: http://dx.doi.org/10.1080/02582473.2010.519904

册 Published online: 10 Dec 2010.

Submit your article to this journal \lceil

Џلll Article views: 369

Q View related articles $\sqsubset$

Citing articles: 1 View citing articles $\square$ 


\title{
HISTORIOGRAPHICAL REVIEW
}

\section{After Race and Class: Recent Trends in the Historiography of Early Colonial Cape Society}

\author{
NIGEL WORDEN* \\ University of Cape Town
}

\begin{abstract}
This article reviews the recent upsurge of writing on the history of the early colonial Cape Colony from the VOC period to the early nineteenth century. It responds to important questions raised by Nicole Ulrich's review article of Contingent Lives in this issue. In particular it considers what is gained and what can be lost in the recent shift from class-based analyses characteristic of late twentieth-century revisionist South African historiography to research more influenced by the 'cultural turn', transnational and microhistorical approaches.
\end{abstract}

Keywords: Cape Colony; VOC; historiography; cultural turn; identity; microhistory; transnational history

This is the second recent issue of South African Historical Journal to be devoted to work on the Cape Colony in the era before the mineral revolution. This new issue has emerged from sessions on the eighteenth- and early nineteenth-century Cape held at the South African Historical Society conference in 2009. In 2007, in a special feature on New Approaches to VOC History, the journal published eight articles that had been originally presented at the Contingent Lives conference held in Cape Town in December 2006. ${ }^{1}$ Clearly the field has been one of considerable recent growth. What does this work do, and where is it heading?

These questions are most incisively posed by Nicole Ulrich's review article of Contingent Lives: Social Identity and Material Culture in the VOC World in this issue. ${ }^{2}$ Ulrich suggestively argues that 'the significance of Contingent Lives extends beyond the historiography of the early colonial Cape as it raises important questions about the writing of history in a post-apartheid and

1 For a discussion of the articles, see N. Worden, 'New Approaches to VOC History in South Africa', South African Historical Journal, 59 (2007), 3 - 18.

2 N. Ulrich, 'Time, Space and the Political Economy of Merchant Capitalism in the Cape of Good Hope and VOC World', South African Historical Journal, 62, 3 (2010), 571 - 588, review of N. Worden, ed., Contingent Lives: Social Identity and Material Culture in the VOC World (Cape Town: Department of Historical Studies, University of Cape Town, 2007).

*Author: Nigel.Worden@uct.ac.za 
increasingly globalised context'. ${ }^{3}$ While welcoming many features of the collection, she expresses concern at a neglect of political economy, an absence of considerations of class especially in relation to the labouring poor, imprecise time specificity and a tendency to decontextualised microstudy and postmodern eclecticism that does little to help us understand the operation of power and authority in a colonial society. In other words, we have turned away from the principles that underpinned South African historical revisionism in the heyday of the 1980s and replaced it with the less cogent ideas and methods that have emerged out of the 'cultural turn'.

These issues match concerns expressed elsewhere about the 'cultural turn' and its relationship to social history. The South Asianist Manu Goswami has recently lamented cultural history's turn away from large-scale approaches, political economy and key areas of imperialism and capitalism. ${ }^{4}$ Geoff Eley in this journal has pointed out that many historians have abandoned 'the earlier totalising ambition, the goal of writing the history of whole societies in some integral and holistic way', but he appeals now for a synthesis since 'between social history and cultural history there is really no need to choose ${ }^{5}$. In South Africa, the break with past historiographical traditions has not been nearly so dramatic or absolute. ${ }^{6}$ Ulrich does not reject the work published in Contingent Lives - far from it - but she warns us against ignoring more materialist and macroscopic insights. Work by historians of the early colonial Cape is of course by no means the only scholarship to have changed the ways in which South African historians think and write since the heyday of vibrant revisionism in the 1970 s and $1980 \mathrm{~s},{ }^{7}$ but consideration of some of these issues in relation to their work may illuminate larger issues about what is happening more broadly in the writing of South African history.

Flattering as it is to have such momentous issues raised around a publication with which one has been involved, Contingent Lives is a surprising choice. It was never intended to have an impact of the kind made by a book with which Ulrich compares it, The Shaping of South African Society, rather being relatively unedited conference proceedings and therefore not commercially available and now out of print. The purpose of the Contingent Lives conference was to bring Cape historians of the seventeenth and eighteenth centuries, the era of Dutch colonial rule, into contact with work of Dutch and Asian scholars on the Dutch East India Company (VOC) in order to open up new lines of thinking. It is thus an eclectic collection, although the re-writing of some of the papers on the Cape for later publication in this journal demonstrated a greater cohesion. The 'Social Identities in Eighteenth-Century Cape Town' research project that hosted the conference is now in the process of producing a (hopefully) much more cogent book which will benefit from not only from the 'Contingent Lives' conference but also the workshops and

$3 \quad$ Ulrich, 'Time, Space', South African Historical Journal 62, 3 (2010) 571 - 588.

4 M. Goswami, '’Remembering the Future', American Historical Review, 113, 1 (2008), 417 - 424.

5 G. Eley, 'Dilemmas and Challenges of Social History since the 1960s: What Comes after the Cultural Turn', South African Historical Journal, 60, 3 (2008), 319, 320. These issues are more fully developed in G. Eley, A Crooked Line: From Cultural History to the History of Society (Ann Arbor: University of Michigan Press, 2007) and the forum that followed it in American Historical Review 113, 1 (2008), 391 - 437. For reflections on this a decade ago, see A. Cobley, 'Does Social History Have a Future? The Ending of Apartheid and Recent Trends in South African Historiography', Journal of Southern African Studies, 27, 3 (2001), 613 625 .

7 See, for example, N. Etherington, 'Is a Reorientation of South African History a Lost Cause?', South African Historical Journal, 60, 3 (2008), 323 - 333. 
seminars that have taken place since 2006, as well as from Ulrich's insightful critique. ${ }^{8}$ The papers in Contingent Lives thus only hint at what was to come.

Writing on early colonial Cape society in the 1970s and 1980s was much less conceptually unified by either structuralist or culturalist approaches to political economy than was the case for most South African revisionist historiography. There were of course exceptions, notably in the work of Martin Legassick and later Susan Newton-King and Wayne Dooling, but many scholars of the Cape such as Robert Ross, Nigel Penn, John Mason and myself, while certainly open to the approaches of culturalist social history coming out of Shula Marks's London seminars or the Witwatersrand History Workshop, were less than fully engaged in them. This raises an important issue. The key tropes of South African revisionism - the forging of a capitalist society and its impact on class consciousness and agency - were less easily transferable to a pre-industrial social order. This made writing on such a period less central to revisionists work. Notable revisionists, such as Bill Freund, Stanley Trapido and Shula Marks, shifted the focus of their initial work on the early Cape Colony to later periods and themes. Although many Cape historians were equally concerned with recovering neglected experiences and histories under colonialism, notably those of slaves and the Khoisan, and certainly did not ignore class and its construction, there was considerably less theoretical rigour and debate in these fields. ${ }^{9}$ Consequently approaches which stress issues of political economy have never been dominant in the writing of pre-industrial Cape history, a notable exception being the work of Dooling (who also pioneered examination of issues of honour and status among Cape slaveowners) as well as an important, but unfortunately unpublished, doctoral thesis by Mary Rayner. ${ }^{10}$

This was evident in the standard revisionist collection on the early Cape, The Shaping of South African Society. ${ }^{11}$ The central issue that preoccupied the editors (if not all of the contributors) was the extent to which early Cape colonial society was racially structured. But this did not provoke the same levels of intense interest as did the 'race-class' debates in relation to later historical periods in South Africa, perhaps because class was much less clearly defined. Instead scholars of the $V O C$ era were more concerned with themes that preoccupied historians of early colonial encounters elsewhere, such as the breakdown of indigenous societies or the experience of slavery. Given the salience of the argument that segregation and apartheid were products of industrial capitalism, early Cape historians after Shaping tended to concentrate on other

The NRF-funded project is fully entitled 'The construction of social identities in 18th century Cape Town in the context of the cultural and material worlds of the Dutch East India Company (VOC)', and was based at the Universities of Cape Town and the Western Cape between 2002 and 2009. The forthcoming book, which I am editing, is to be published by Jacana Press in Johannesburg and Verloren in Hilversum and will hopefully appear in 2011 .

9 As Colin Bundy pointed out in an exchange with Patrick Harries at the conference 'Cape Slavery - And After' held at University of Cape Town in 1989 in which the neglect of class was highlighted. A critique of the use of class by early colonial Cape historians was highlighted in H. Bradford, 'Highways, Byways and Cul-de-Sacs: The Transition to Agrarian Capitalism in Revisionist South African History’, Radical History Review, 46 - 47 (1990), $59-88$.

10 W. Dooling, Law and Community in a Slave Society: Stellenbosch District, South Africa, c.1760 - 1820 (Cape Town: Centre for African Studies, University of Cape Town, 1992); W. Dooling. Slavery, Emancipation and Colonial Rule in South Africa (Scottsville: University of KwaZulu-Natal Press, 2007); M. Rayner, 'Wine and Slaves: The Failure of an Export Economy and the Ending of Slavery in the Cape Colony, South Africa, 1806 1834' (PhD thesis, Duke University, 1986).

11 R. Elphick and H. Giliomee, eds, The Shaping of South African Society, 1652 - 1820 (Cape Town: Maskew Miller Longman, 1979; $2^{\text {nd }}$. ed. 1989). 
concerns and to be somewhat suspicious of categories that were more evidently applicable to later periods. Discussions of the inter-relationship of race and class at the Cape came instead to focus on the mid- to later-nineteenth century, most notably brought together in an important synthesis by Timothy Keegan who, as Ulrich points out, was unsympathetic to rigid class models. ${ }^{12}$ The roots therefore of what Ulrich describes as a questioning by pre-industrial Cape historians of 'totalising meta-narratives of social formation and resistance - especially around race, class and nation-go' deep. ${ }^{13}$

Instead, Cape scholars in the 1990s started turning to new themes. It is perhaps not coincidental that the pioneers among them were based outside South Africa where they were more strongly influenced by the impact on historians of the 'cultural turn'. John Mason's articles on Cape slavery in the nineteenth century used micronarrative to probe issues of honour, status and slave consciousness. ${ }^{14}$ Robert Ross, the most prolific and innovative of early Cape historians, heralded the way with the publication in 1999 of Status and Respectability in the Cape Colony, 1750 1870: A Tragedy of Manners, a book which marked a shift from his earlier focus on issues of slave resistance and Cape economic, demographic and social structure. ${ }^{15}$ By examining changing cultural practices such as dress, language, rituals, ceremony, forms of education and concepts of politeness between the $V O C$ period and the eve of the mineral revolution, Ross demonstrated how concepts of white racism and resistance to it were embodied in everyday cultural practice. Class, race and the operation of political power were certainly not neglected - indeed they are central to Ross's argument that 'respectability was the outward manifestation of a specific class ideology' - but they were shown to be pliable categories embedded in everyday actions and thought. ${ }^{16}$ This approach matched some of the work of historical archaeologists in Cape Town, largely under the inspiration of Martin Hall, who applied ideas about the symbolic meanings of material culture to explicate social practices and power, most notably in his argument that the Cape gable was a marker of status and prestige rather than merely an architectural fancy. More recent work by Antonia Malan and Yvonne Brink has taken this approach much further. ${ }^{17}$

T. Keegan, Colonial South Africa and the Origins of the Racial Order (Cape Town: David Philip, 1996). The book virtually ignores the period before 1800. See also A. Bank, 'Losing Faith in the Civilizing Mission: The Premature Decline of Humanitarian Liberalism at the Cape, 1840 - 60', in M. Daunton and R. Halpern, eds, Empire and Others: British Encounters with Indigenous Peoples, 1600 - 1850 (Philadelphia: University of Pennsylvania Press, 1999), 364 - 383; A. Bank, 'Liberals and their Enemies: Racial Ideology at the Cape of Good Hope, 1820 to 1850 ' (Ph.D thesis, University of Cambridge, 1995).

13 Ulrich, 'Time, Space', South African Historical Journal, 62 (3) 2010.

14 For example, J. Mason, 'Hendrik Albertus and his Ex-Slave Mey: A Drama in Three Acts', Journal of African History, 31 (1990), 423 - 445. This was later developed in his vivid explication of slave cultural and social life, Social Death and Resurrection: Slavery and Emancipation in South Africa (Charlottesville, London: University of Virginia Press, 2003).

15 R. Ross, Status and Respectability in the Cape Colony, 1750 - 1870 (Cambridge: Cambridge University Press, 1999). Key examples of earlier work by Ross include Cape of Torments: Slavery and Resistance in South Africa (London: Routledge, 1983); 'The Rise of the Cape Gentry', Journal of Southern African Studies, 9 (1983), 193 - 217; and the collection of articles in Beyond the Pale: Essays on the History of Colonial South Africa (Johannesburg: Witwatersrand University Press, 1994).

16 Ross, Status and Respectability, $4-5$.

17 M. Hall, 'The Secret Lives of Houses: Women and Gables in the Eighteenth Century Cape', Social Dynamics, 20, 1 (1994), 1 - 48. See also M. Hall, Archaeology and the Modern World: Colonial Transcripts in South Africa and the Chesapeake (London: Routledge, 2000); A. Malan, 'The Archaeology of Probate Inventories', Social Dynamics, 16, 1 (1990), 1 - 10; G. Lucas, An Archaeology of Colonial Identity: Power and Material Culture in 
It is thus indeed the case that many Cape historians were tending strongly towards the cultural turn at the time of the Contingent Lives conference, although by no means all of the papers presented there followed this approach, and very few embraced it wholeheartedly. We need therefore to consider some of the main implications of this work.

A key element is that the concept of identity has seemingly replaced the centrality of class. This is the result of the influence of rich work by early modern Europeanists around identity issues, especially as they relate to gender. ${ }^{18}$ Such work has been highly insightful for historians of the seventeenth and eighteenth centuries, and the 'Social Identities' project has been much concerned with testing out its application in the colonial context. Ulrich rightly points out that identity can be a slippery word, rarely defined, imprecise in its meaning. This need not, however, be the case. British empire historian Kathleen Wilson has usefully argued that 'identity results from the negotiation between where one is placed and where one places oneself within social networks, working through what is possible and what is forbidden'. ${ }^{19}$ This needs to be historically precise and demonstrable through awareness of how people were placed in society, what was possible and what was forbidden to them, what social networks they constructed or belonged to and how they viewed themselves as individuals, collectively, and in relation to others. The performative, that is the ways in which people defended or promoted their own identities, becomes a central concern of the historian. This can be in terms of social attitudes, patterns of work, living space and leisure, language, dress and gesture, consumption and material belongings. Crucially, we need to ask how similar and different were these features across or within class lines? Issues of power and agency, central to a materialist approach, are thus by no means neglected, and we certainly need to remain aware of the constraints that they impose on cultural autonomy. As advocates of the cultural turn such as Antoinette Burton have stressed, the 'new cultural history' is grounded in power relations and materiality as well as in representation. ${ }^{20}$ But class defined by relations of production is no longer the only way by which historians can explore how people in the past perceived themselves and others. Gender, ethnicity, age, belief systems and a host of other potential identifiers played a crucial part in social consciousness which a class analysis can obscure.

If I may cite an example from my own work, many sailors from $V O C$ ships who came ashore in Cape Town in the mid-eighteenth century did not identify themselves with other Capetonians of the labouring classes, whether Asian or African slaves, European soldiers or

the Dwars Valley, South Africa (New York: Springer, 2006); Y. Brink, They Came to Stay: Discovering Meaning in the 18th Century Cape Country Dwelling (Stellenbosch: SUN Press, 2008).

18 From a vast literature, see, for example (to cite some of the works which have most influenced me), S. Schama, The Embarrassment of Riches: An Interpretation of Dutch Culture in the Golden Age (London: Collins, 1987); J. Farr, Hands of Honor: Artisans and their World in Dijon, 1550 - 1650 (Ithaca: Cornell University Press, 1988); L. Roper, Oedipus and the Devil: Witchcraft, Sexuality and Religion in Early Modern Europe (London: Routledge, 1994); K. Stuart, Defiled Trades and Social Outcasts: Honor and Ritual Pollution in Early Modern Germany (Cambridge: Cambridge University Press, 1999); U. Rublack, Gender in Early Modern Germany (Cambridge: Cambridge University Press, 2002); and H. Roodeburg, ed., Forging European Identities, 1400 - 1700 (Cambridge: Cambridge University Press, 2007). A particularly fruitful exchange in this regard took place at the workshop 'On the Frontiers of Europe: The Cape of Good Hope in the $17^{\text {th }}$ and $18^{\text {th }}$ Centuries', held between members of the 'Social Identities' project and Europeanists at the University of Basel in December 2009. K. Wilson, The Island Race: Englishness, Empire and Gender in the Eighteenth Century (London and New York: Routledge, 2003), 2 - 3.

20 A. Burton, 'Thinking beyond the Boundaries', Social History, 26, 1 (2001), 60 - 71. 
other lower-ranking Company employees. ${ }^{21}$ As Ulrich suggests, we might expect to find such a class solidarity and forms of collective action, following Peter Linebaugh and Marcus Rediker's suggestive work on the revolutionary ideas of the Atlantic world, and I began my research with the expectation of doing so. ${ }^{22}$ However, the evidence is simply not there for much of the eighteenth century. Rather, I found that many VOC sailors had their own distinctive forms of language, socialisation, and cultural identity, rooted in a distinctive maritime world that other Cape Town labourers did not share. ${ }^{23}$ What is interesting is how far these distinctions of identity marked through cultural practices may have shifted, or been overcome, in the late eighteenth and early nineteenth centuries, especially as more Asian crewmen came ashore. Certainly, there is evidence that some Cape slaves demonstrated a growing awareness of wider class solidarity in the 1780s and 1790s, marked most notably in the 1808 Swartland uprising when slaves, Khoi workers and Irish soldiers joined forces - although in ways which I have argued revealed distinctive symbolic reversals of the cultural practices of slave masters and their slaves. ${ }^{24} \mathrm{Nicole}$ Ulrich's own current doctoral research is providing much more insight into this process. ${ }^{25} \mathrm{We}$ must certainly not ignore class, and particularly not in moments of conflict, but neither must we over-exaggerate collective class consciousness or ignore the cultural distinctions within class that manifest themselves in social practice and encounter.

Wilson also stresses that the formation of cultural identity is 'a historical process, identity is tentative, multiple and contingent, and its modalities change over time'. ${ }^{26}$ Ulrich rightly stresses that we ignore this at our peril. It has indeed been one of the aims of the 'Social Identities' project to challenge a static and ahistorical analysis of one and a half centuries of VOC rule. Ross heralds the way in Status and Respectability by identifying important shifts in the nature of social identities, especially in the period of transition to British colonial rule in the early nineteenth century. Karel Schoeman alerts us to the need to distinguish the instabilities of social organisation in the earliest decades of the colony before the 1710s from what came later, while Gerald Groenewald has carefully distinguished the economic, kinship and political networks of Cape Town mercantile elites in the 1730 s from that of the $1770 \mathrm{~s}^{27}$

So what do these approaches overlook? Ulrich is rightly concerned by a focus in Contingent Lives on the dominant classes, such as merchants, free burghers and landowners to the neglect of the labouring poor. Are we returning to an elitist view of social relations? In this regard, however, the conference proceedings are misleading as a guide to recent Cape historiography. The very

21 N. Worden, 'Strangers Ashore: Sailor Identity and Social Conflict in Mid-18th Century Cape Town', Kronos, 33 (2007), $72-83$.

22 P. Linebaugh and M. Rediker, The Many-Headed Hydra: Sailors, Slaves, Commoners and the Hidden History of the Revolutionary Atlantic (London: Verso, 2000).

23 The classic study of this distinctive culture is of course another of Marcus Rediker's works, Between the Devil and the Deep Blue Sea (Cambridge: Cambridge University Press, 1987).

24 N. Worden, “Armed with Swords and Ostrich Feathers”: Militarism and Cultural Revolution in the Cape Slave Uprising of 1808', in R. Bessel, N. Guyatt and J. Rendall, eds, War, Empire and Slavery, 1770 - 1830 (London: Palgrave, 2010), $121-138$.

25 N. Ulrich, 'Abolition from Below: The 1808 Revolt in the Cape Colony', in M. van der Linden, ed., 'Humanitarian Intervention' and Changing Labour Relations: Long-Term Consequences of the British Act on the Abolition of the Slave Trade, 1807 (Leiden and Boston: Brill, 2010), forthcoming.

26 Wilson, Island Race, 3.

27 K. Schoeman, Armosyn van die Kaap: Die Wêreld van 'n Slavin, 1652 - 1733 (Cape Town: Human and Rousseau, 2001); G. Groenewald, 'Kinship, Entrepreneurship and Social Capital: Alcohol Pachters and the Making of a Free-Burgher Society in Cape Town, 1652 - 1795' (PhD thesis, University of Cape Town, 2010). 
prevalence of earlier work on slavery and the nature and destruction of Khoi and San societies meant that Cape historians at the conference were now turning to examine the dominant classes, hitherto treated as a cohesive unity, in order to unpick the ways in which they constructed their world and sought to control it. But they have been equally concerned to explore how those at the lower ranks of the social order identified themselves. Recent studies of eighteenth-century Cape Town have focused on soldiers, sailors, slaves, exiles and convicts. Kerry Ward's Networks of Empire shows how the presence of Asian convicts and exiles undermined hierarchies of race and status in the early colony and there has been a focus on the meanings of status and honour among artisans, soldiers and slaves. ${ }^{28}$

Ward's book has also been path-breaking in the ways it links the VOC Cape to the wider context of imperial networks in the early modern Indian Ocean world. Many other Cape historians have tended to be more influenced by early modern European writing than by the innovative findings of the new imperial history, as Ulrich tellingly points out. In particular, she also believes that we need to pay more attention to merchant capitalism and its operation. In this, she is undoubtedly correct, although I would suggest only if we remain sensitive to the limitations of an all-embracing economistic model. One of the striking features of the operation of the $V O C$ within Asia is just how limited was its ability to influence local means of production and exchange. Instead of a monolithic and monopolistic mercantilist project, the view from the Indian Ocean is of an array of administrators, traders and soldiers engaging with indigenous social formations, sometimes successfully, often not. This is why, as Ulrich points out, Heather Sutherland's chapter in Contingent Lives is so insightful, because it illustrates how a Western understanding of diplomacy, trade and politics is re-interpreted and negotiated within Asian cultural norms and practices. Similarly, Ward shows in Networks of Empire that exile was a form of diplomacy embedded in Southeast Asian court politics, rather than solely an illustration of the strong arm of European merchant capitalism. Ulrich finds this kind of analysis insightful but also limiting, since we do not know if it marks 'emerging modernity, recalcitrant traditionalism, or distinct features of merchant colonialism' ${ }^{29}$ I would suggest that such examples are useful precisely because they reveal the limitations of these kinds of overarching labels. As Ward's work suggests, the VOC empire did not represent a single form of 'merchant colonialism', much as we might like to categorise it as such.

This leads to a more fundamental methodological issue, that of how, or if, historians should transcend the micro-narratives so beloved of cultural historians (certainly many of those working on the Cape, although few do so in a strictly Ginzburgian sense). The new Cambridge History of South Africa, for example, states in its discussion of the recent historiography of the early colonial Cape that 'the strength of such work has been in reconstructing microhistories, which

K. Ward, Networks of Empire: Forced Migration in the Dutch East India Company (New York: Cambridge University Press, 2008). On honour, see N. Worden, 'Forging a Reputation: Artisan Honour and the Cape Town Blacksmith Strike of 1752', Kronos, 28 (2002), 43 - 65; N. Worden, 'Demanding Satisfaction: Violence, Masculinity and Honour in Late Eighteenth-Century Cape Town', Kronos, 35 (2009), 32 - 47; N. Taylor, 'A Scapegoat of Status on the Streets of $18^{\text {th }}$ Century Cape Town', Historical Approaches, 4 (2007), 12 - 18. For the nineteenth century, see especially P. Scully, Liberating the Family?: Gender and British Slave Emancipation in the Rural Western Cape, South Africa, 1823 - 1853 (Portsmouth, NH: Heinemann and Cape Town: David Philip, $1997)$ and the work in progress by Rick Watson on honour and violence among slaves. 
as yet await full incorporation into a wider understanding of Cape society' ${ }^{30}$ This of course is part of a far larger debate about meta-narratives and their role in the writing of history. South African historians have been particularly wedded to the idea that we can and should interpret the past through such means, whether it take the form of a nationalist triumphalism or materialist determinism. One of the great achievements of the revisionists of the 1980s was their ability to combine the specifics of case studies with the broader narrative of agency within a capitalist society in the making. In the case of early colonial Cape historians, we seem to be working in the other direction. Lacking an overarching materialist model of the kind that structuralists produced for industrialising South Africa, pre-industrial historians are instead producing detailed local studies in order to recover hidden histories - such as those of soldiers, free blacks, convicts, female labourers - but also to destabilise assumptions about, for example, settler cohesion and racial stratification. They are concerned to show that the Cape was a more complex society than is often assumed, and one in which the old debates about race and class need to be reworked. Explanation, rather than mere description, is their main purpose, since one of the goals of microhistories is to 'sharpen the focus of history rather than limit its aims'. ${ }^{31}$ These broader arguments are not yet clearly apparent and microhistorians need to be more aware of what their work illuminates. The best microstudies (such as those of Nigel Penn) are already doing this.

Other methods such as the use of prosopography or collective biographical data, are evident in the work of Gerald Groenewald, Laura Mitchell and Teun Baartman, which combine detailed case studies of kinship with identification of broader patterns of social, economic and political behaviour. ${ }^{32}$ But there are many gaps. It is for example, indeed time to re-examine some of the institutional mechanisms by which the VOC operated, as Ulrich points out. And she is also correct to draw our attention to the ways in which scholars of colonialism such as Ann Stoler can deepen our understanding of the ways in which gender, kinship, family and sexuality are politically and economically determined. ${ }^{33}$

A somewhat different picture emerges when we turn to recent work on the nineteenth-century Cape Colony. Such scholarship has attracted more attention from historians, including many outside South Africa, perhaps because of the greater linguistic accessibility of source material in English, but also because the nineteenth-century Cape became part of an imperial network under British rule which has received more focused attention internationally. So, in addition to topics which have developed as a result of local work (such as the nature of slave and Khoi labour, frontier conflicts and San genocide) - themes familiar to historians of other British colonies in this period - (such as antislavery, abolitionism and the humanitarian lobby, the impact of missionaries and the reconstruction of a post-emancipation labour force) - have received

30 R. Ross, 'Khoesan and Immigrants: The Emergence of Colonial Society in the Cape, 1500 - 1800', in C. Hamilton, B. Mbenga and R. Ross, eds, The Cambridge History of South Africa, Vol. I (Cambridge: Cambridge University Press, 2010), 169.

31 E. Muir, 'Microhistory or Microstoria', in K. Boyd, ed., Encyclopedia of Historians and Historical Writing, Vol. II (London: Fitzroy Dearborn, 1998 - 1999), 616.

32 Groenewald, 'Kinship, Entrepreneurship and Social Capital'; L. Mitchell, Belongings: Property, Family and Identity in Colonial South Africa (An Exploration of Frontiers, 1725 - c.1830) (New York: Columbia University Press, 2009); T. Baartman, 'The Role of the Burghers and Factions in the Politics of Cape Town at the End of the Eighteenth Century', (PhD thesis, University of Cape Town, forthcoming).

33 A. Stoler, Carnal Knowledge and Imperial Power: Race and the Intimate in Colonial Rule (Berkeley: University of California Press, 2002). 
considerable attention. ${ }^{34}$ A particular recent focus is transnational, looking beyond the colony itself to wider links and connections in which the Cape was integrated. Thus Alan Lester has examined the nature of British settler discourse in the context of forces within the metropolis and other parts of the expanding British empire, while Elizabeth Elbourne, Kirsten McKenzie and Nigel Penn have both drawn attention to ways in which the Australian and Cape colonies were connected by mutually developed policies, personnel and experiences. ${ }^{35}$ The nineteenth-century Cape has been much better integrated into this international scholarship than has been the case for the eighteenth-century colony.

One strong topic to emerge is the nature of colonial Britishness, a key theme of Ross's Status and Respectability. McKenzie's comparative studies of Cape Town and Sydney have focused on the constructions of a colonial middle-class identity, using rich material on gossip, scandal and the manifestations of new concepts of individual liberties. ${ }^{36}$ Helen Ludlow's current research on government teachers in the mid-nineteenth century Cape, the first fruits of which are published in this issue, examines the problems of putting a new educational system based on British (and more specifically Scottish) ideals into practice. Central to this is consideration of teacher identities, cultural manifestations and performances, strongly influenced by the ideas of the cultural turn.

There is clearly much further work to be done in this area. Transnational research requires international co-operation. A hopeful sign in this direction is a new postgraduate course taught jointly at the Universities of Cape Town and Sydney entitled 'Southern Crossings: Australia and the Cape, $1750-1850$ '. In addition, Penn has been supervising a series of senior undergraduate student research essays at the University of Cape Town on the use of convict labour for the construction of mountain passes in the mid-nineteenth century Cape which turns a transnational theme towards the experiences of labour. A promising area of future research, heralded by Ulrich's work, is the period of transition from Dutch to British rule and the ways in which new concepts of revolution and reaction swirling around the Atlantic world between the 1780s and 1810s played themselves out in the Cape, and not only in relation to its elites. A bridging of periods of VOC and subsequent colonial administrations would be a fruitful development. Ward has pointed the way by identifying how networks within the Dutch colonial world transmuted into those of

For example, E. Elbourne, Blood Ground: Colonialism, Missions and the Contest for Christianity in the Cape Colony and Britain, 1799 - 1853 (Montreal and Kingston: McGill-Queen's University Press, 2002); Scully, Liberating the Family?; Bank, 'Losing Faith'; and the collected essays in N. Worden and C. Crais, eds, Breaking the Chains: Slavery and its Legacy in the Nineteenth-Century Cape Colony (Johannesburg: Witwatersrand University Press, 1994).

35 A. Lester, Imperial Networks: Creating Identities in Nineteenth-Century South Africa and Britain (London: Routledge, 2001); A. Lester, 'British Settler Discourse and the Circuits of Empire', History Workshop Journal, 54 (2002), 24 - 48; Elbourne, Blood Ground; E. Elbourne, The Sin of the Settler: The 1835 - 36 Select Committee on Aborigines and Debates over Virtue and Conquest in the Early Nineteenth-Century British White Settler Empire', Journal of Colonialism and Colonial History, 4, 3 (2003), 1 - 49; E. Elbourne, 'Between Van Diemen's Land and the Cape Colony', in A. Johnston and M. Rolls, eds, Reading Robinson: Companion Essays to "Friendly Mission” (Hobart: Quintus Publishing, 2008), 77 - 94; N. Penn, 'Close and Merciful Watchfulness': The Origins and Nature of John Montagu's Convict System in the Mid-Nineteenth Century Cape Colony', Cultural and Social History, 5, 4 (2008), 465 - 480; K. McKenzie, 'Of Convicts and Capitalists: Honour and Colonial Commerce in Cape Town and Sydney’, Australian Historical Studies, 118 (2002), 199 - 222.

36 K. McKenzie, Scandal in the Colonies: Sydney and Cape Town, 1820 - 1840 (Melbourne: Melbourne University Press, 2004); K. McKenzie, 'Women's Talk and the Colonial State: The Wylde Scandal, 1831 - 1833', Gender and History, 11, 1 (1999), 30 - 53; K. McKenzie, A Swindler's Progress: Nobles and Convicts in the Age of Liberty (Sydney: University of New South Wales Press, 2009). 
British imperial linkages in the Indian Ocean region, in which the Cape's position built on earlier connections. $^{37}$

A further element emerging in early colonial Cape studies is an examination of the nature of texts, their circulation and reception. Following illuminating work in this regard in relation to other early colonial societies, some Cape historians have begun to probe the ways in which written texts created and circulated forms of knowledge (there is still little awareness of visual texts). An important impetus has been given by Siegfried Huigen's studies of Cape traveller accounts. ${ }^{38}$ The Contingent Lives conference brought Adrien Delmas to South Africa, whose doctoral work in Paris has explored the ways in which a range of seventeenth-century VOC texts have been produced and circulated. ${ }^{39}$ Together with Penn, he organised a conference in Cape Town in 2008, which brought Cape historians into contact with the rich work of Latin American scholars on the nature and production of texts in the early modern colonial world. Its imminent publication will give much greater prominence to such approaches in South Africa. ${ }^{40}$

As Ulrich points out, Cape scholars need to be more aware of the ways in which the colonial archive has been constructed, and sensitive to the power dynamics that lie behind the texts they use. A problem for many Anglophone South Africans is that the $V O C$ records, rich as they may be, are written in a relatively unfamiliar language and housed in an archive which is not sympathetic to online public access. The recent publication by the Van Riebeeck Society of a selection of judicial records concerning Cape slaves made these key sources more widely available. This issue of the journal contains a paper by Jessica Murray ${ }^{41}$ which draws on their translations to offer a gendered reading of slavery, set alongside a recent fictional account of slave experience. ${ }^{42}$ Many historians of the Cape used the English translations of traveller accounts which can provide a wealth of information about all levels of the Cape society. Ulrich has recently shown how such accounts can be read 'across the grain' to provide insights into the Cape labouring poor in the late eighteenth century. ${ }^{43}$

Two other articles in this issue reflect the growing interest in literary texts and their circulation. Christopher Holdridge examines not only the content but also the circulation and reception of Sam Sly's African Journal in order to explore the way in which local readers shaped their identities in a transnational context of developing notions of Britishness. ${ }^{44}$ David Johnson has

37 Ward, Networks of Empire, 283 - 307.

38 S. Huigen, De Weg naar Monomotopa: Nederlandstalige Representaties van Geographische, Historische en Scoiale Werkelijkheden in Zuid-Afrika (Amsterdam: Amsterdam University Press, 1996); S. Huigen, Knowledge and Colonialism: Eighteenth-Century Travellers in South Africa (Leiden: Brill, 2009).

39 A. Delmas, 'Les Voyages du Récits: Culture Écrite et Expansion Européenne: Le Cas de la VOC au XVIIe Siècle' (Doctoral dissertation, EHESS, Paris, 2010).

40 A. Delmas and N. Penn, eds, Written Culture in a Colonial Context $16^{\text {th }}-19^{\text {th }}$ Centuries (Cape Town: UCT Press, 2010).

41 J. Murray, 'Gender and Violence in Cape Slave Narratives and Post-Narratives', South African Historical Journal, 62, (3) 2010), $444-462$.

42 N. Worden and G. Groenewald, eds, Trials of Slavery: Selected Documents Concerning Slaves from the Criminal Records of the Council of Justice at the Cape of Good Hope, 1705 - 1794 (Cape Town: Van Riebeeck Society, 2005). Encouraging as this is, I have to confess that the traditionalist in me is concerned when scholars completely substitute these edited translations for the more voluminous original documents.

43 N. Ulrich, 'Dr Anders Sparrman: Travelling with the Labouring Poor in the Late Eighteenth-Century Cape', South African Historical Journal 61, 4 (2009), 731 - 749.

44 C. Holdridge, 'Circulating the African Journal: The Colonial Press and Trans-Imperial Britishness in the MidNineteenth Century Cape’, South African Historical Journal, 62, (3) 2010), 487 - 513. 
identified the ways in which Cape history has been represented in novels and other fictional texts. He is concerned with how the Cape past has been re-worked by writers of fiction and in the process has unearthed a wealth of long-forgotten material..$^{45} \mathrm{He}$ thus points us towards the ways in which the Cape past has been used to bolster, shape and (more rarely) contest contemporary ideologies and power dynamics.

This brings us to the issue of the politics of history. Much of the impetus behind the revisionist work of the 1970s and 1980s came from a strong commitment by historians to changing the existing order, and in particular to demonstrating how ordinary men and women in the past and by implication in the present - could be active agents in the making of their own history. Agency and collective class consciousness were crucial to destroying apartheid and the capitalist order that had produced it, and many historians saw their research as contributing in some ways towards that destruction.

The history of the Cape's early colonial past remained on the fringes of these concerns. Colonial expropriation of Khoi, San and Xhosa land fitted into a narrative of the destruction of indigenous social formations, but did not feature strongly in the accounts that placed primacy on the peculiar nature and impact of South African industrialisation. Cape slavery, in notable contrast to its mobilisation among North American, Caribbean and Brazilian historians and activists, remained an oddity, a minority experience of those who could not claim to be indigenous and whose roots lay (at least in part) outside Africa. ${ }^{46}$ Such a disparity was clearly revealed in a recent conference held at the Slave Lodge in Cape Town (and reviewed in this issue), organised by the Wilberforce Institute for the Study of Slavery and Emancipation at the University of Hull, where the complexities of South African and Indian Ocean slavery and its identity politics contrasted with the somewhat one-dimensional and triumphalist story of Atlantic slavery and its abolition.

Is therefore a readiness to turn towards the cultural among early colonial Cape historians a sign of their sense of detachment from what Eley has described as 'the utopia of social history, which was borne by a vital and energising dialectic between the forms of history many of us thought could explain the world and the types of politics we believed could change it'? ${ }^{47}$ This is not to say that Cape historians have been absent from wider public issues such as land claims or public history initiatives. But there is a sense in which the national project has been less powerful, and more contested, in relation to the Cape's past and its present. Instead, as the editors of the Cambridge History of South Africa point out, new themes in historical writing have emerged which reflect the fact that 'issues of identity and subjectivity loomed large in public discourse as South Africans grappled with the challenges of reimagining themselves and breaking free of the institutions and inherited structures that had define apartheid identities' ${ }^{48}$

This may well explain why Cape historians have readily embraced issues of identity, transnational themes and international historiographical trends in the post-apartheid era. They are by no means alone in this - as Ulrich points out, labour and maritime historians at the Wits

D. Johnson, 'Historical and Literary Re-iterations of Dutch Settler Republicanism', South African Historical Journal, 62, (3) 2010), 463 - 486.

46 N. Worden, 'The Changing Politics of Slave Heritage in the Western Cape, South Africa', Journal of African History, 50 (2009), $23-40$.

47 Eley, 'Dilemmas and Challenges', 311.

48 C. Hamilton, B. Mbenga and R. Ross, 'The Production of Preindustrial South African History', in C. Hamilton, B. Mbenga and R. Ross, eds, Cambridge History of South Africa, Vol. I (Cambridge: Cambridge University Press, 2010), 56. 
Institute for Social and Economic Research (WISER) have also identified the significance of Indian Ocean transnational processes. But we are only scraping the surface at present. We are all still largely ignorant of Latin American, Asian and Australasian connections with which we can fruitfully engage. We do not need to abandon our commitment to South African realities by doing so.

Ulrich's review of Contingent Lives thus points us in important directions. It is a wake-up call to the dangers of getting so immersed in the cultural turn that we forget the legacy of South African revisionist scholarship. But we need to push the boundaries of historical methods and ideas further. At present historians of the early colonial Cape are only starting to connect with innovative scholarship among other scholars of the colonial encounter. In the coming decade it will be seen whether we can rise to Ulrich's challenge to produce macro-histories which draw on this new work to offer a distinctive South African contribution to an understanding of the early colonial past.

\section{References}

Baartman, T., 'The Role of the Burghers and Factions in the Politics of Cape Town at the End of the Eighteenth Century' ( $\mathrm{PhD}$ thesis, University of Cape Town, forthcoming).

Bank, A., 'Losing Faith in the Civilizing Mission: The Premature Decline of Humanitarian Liberalism at the Cape, 1840 - 60', in M. Daunton and R. Halpern, eds, Empire and Others: British Encounters with Indigenous Peoples, 1600 - 1850 (Philadelphia: University of Pennsylvania Press, 1999), 364 - 383.

Bradford, H., 'Highways, Byways and Cul-de-Sacs: The Transition to Agrarian Capitalism in Revisionist South African History', Radical History Review, 46 - 47 (1990), 59 - 88.

Brink, Y., They Came to Stay: Discovering Meaning in the 18th Century Cape Country Dwelling (Stellenbosch: SUN Press, 2008).

Burton, A., 'Thinking beyond the Boundaries', Social History, 26, 1 (2001), 60 - 71.

Cobley, A., 'Does Social History Have a Future?: The Ending of Apartheid and Recent Trends in South African Historiography', Journal of Southern African Studies 27, 3 (2001), 613 - 625.

Delmas, A., 'Les Voyages du Récits: Culture Écrite et Expansion Européenne: Le Cas de la VOC au XVIIe Siècle' (Doctoral dissertation, L'École des Hautes Études en Sciences Sociales [EHESS], Paris, 2010).

Delmas, A. and Penn, N., eds, Written Culture in a Colonial Context 16 $6^{\text {th }}-19^{\text {th }}$ Centuries (Cape Town: UCT Press, 2010).

Dooling, W., Law and Community in a Slave Society: Stellenbosch District, South Africa, c.1760 - 1820 (Cape Town: Centre for African Studies, University of Cape Town, 1992).

Dooling, W., Slavery, Emancipation and Colonial Rule in South Africa (Scottsville: University of KwaZulu-Natal Press, 2007).

Elbourne, E., Blood Ground: Colonialism, Missions and the Contest for Christianity in the Cape Colony and Britain, 1799 - 1853 (Montreal and Kingston: McGill-Queen's University Press, 2002).

Elbourne, E., 'The Sin of the Settler: The 1835 - 36 Select Committee on Aborigines and Debates over Virtue and Conquest in the Early Nineteenth-Century British White Settler Empire', Journal of Colonialism and Colonial History, 4, 3 (2003), 1 - 49.

Elbourne, E., 'Between Van Diemen's Land and the Cape Colony', in A. Johnston and M. Rolls, eds, Reading Robinson: Companion Essays to 'Friendly Mission'(Hobart: Quintus Publishing, 2008), 77 - 94.

Eley, G., A Crooked Line: From Cultural History to the History of Society (Ann Arbor: University of Michigan Press, 2007).

Eley, G., 'Dilemmas and Challenges of Social History since the 1960s: What Comes after the Cultural Turn?', South African Historical Journal, 60, 3 (2008), 310 - 322.

Elphick, R. and Giliomee, H., eds, The Shaping of South African Society, 1652 - 1820 (Cape Town: Maskew Miller Longman, 1979).

Elphick, R. and Giliomee, H., eds, The Shaping of South African Society, 1652 - 1840 (Cape Town: Maskew Miller Longman, 1989).

Etherington, N., 'Is a Reorientation of South African History a Lost Cause?', South African Historical Journal, 60, 3 (2008), $323-333$. 
Farr, J., Hands of Honor: Artisans and their World in Dijon, 1550 - 1650 (Ithaca: Cornell University Press, 1988).

Goswami, M., 'Remembering the Future', American Historical Review, 113, 1 (2008), 417 - 424.

Groenewald, G., 'Kinship, Entrepreneurship and Social Capital: Alcohol Pachters and the Making of a Free-Burgher Society in Cape Town, 1652 - 1795' (PhD thesis, University of Cape Town, 2010).

Hall, M., 'The Secret Lives of Houses: Women and Gables in the Eighteenth Century Cape', Social Dynamics 20, 1 (1994), $1-48$.

Hall, M., Archaeology and the Modern World: Colonial Transcripts in South Africa and the Chesapeake (London: Routledge, 2000).

Hamilton, C., Mbenga, B. and Ross, R., 'The Production of Preindustrial South African History', in C. Hamilton, B. Mbenga and R. Ross, eds, Cambridge History of South Africa, Vol. I (Cambridge: Cambridge University Press, 2010), $1-62$.

Holdridge, C., 'Circulating the African Journal: The Colonial Press and Trans-Imperial Britishness in the Mid-Nineteenth Century Cape', South African Historical Journal, 62, (3) 2010), 487 - 513.

Huigen, S., De Weg naar Monomotopa: Nederlandstalige Representaties van Geographische, Historische en Sociale Werkelijkheden in Zuid-Afrika (Amsterdam: Amsterdam University Press, 1996).

Huigen, S., Knowledge and Colonialism: Eighteenth-Century Travellers in South Africa (Leiden: Brill, 2009).

Johnson, D., 'Historical and Literary Re-iterations of Dutch Settler Republicanism', South African Historical Journal, 62 , (3) 2010, $463-486$.

Keegan, T., Colonial South Africa and the Origins of the Racial Order (Cape Town: David Philip, 1996).

Lester, A., Imperial Networks: Creating Identities in Nineteenth-Century South Africa and Britain (London: Routledge, 2001).

Lester, A., 'British Settler Discourse and the Circuits of Empire', History Workshop Journal, 54 (2002), 24 - 48.

Linebaugh, P. and Rediker, M., The Many-Headed Hydra: Sailors, Slaves, Commoners and the Hidden History of the Revolutionary Atlantic (London: Verso, 2000).

Lucas, G., An Archaeology of Colonial Identity: Power and Material Culture in the Dwars Valley, South Africa (New York: Springer, 2006).

Malan, A., 'The Archaeology of Probate Inventories', Social Dynamics, 16, 1 (1990), 1 - 10.

Mason, J., 'Hendrik Albertus and his Ex-Slave Mey: A Drama in Three Acts', Journal of African History, 31 (1990), $423-445$.

McKenzie, K., 'Of Convicts and Capitalists: Honour and Colonial Commerce in Cape Town and Sydney', Australian Historical Studies, 118 (2002), 199 - 222.

McKenzie, K., Scandal in the Colonies: Sydney and Cape Town, 1820 - 1840 (Melbourne: Melbourne University Press, 2004).

McKenzie, K., 'Women's Talk and the Colonial State: The Wylde Scandal, 1831 - 1833', Gender and History, 11, 1 (1999), $30-53$.

McKenzie, K., A Swindler's Progress: Nobles and Convicts in the Age of Liberty (Sydney: University of New South Wales Press, 2009).

Mitchell, L., Belongings: Property, Family and Identity in Colonial South Africa (An Exploration of Frontiers, 1725 c.1830) (New York: Columbia University Press, 2009).

Muir, E., 'Microhistory or Microstoria', in K. Boyd, ed., Encyclopedia of Historians and Historical Writing, Vol. II (London: Fitzroy Dearborn, 1998 - 1999), 615 - 617.

Murray, J., 'Gender and Violence in Cape Slave Narratives and Post-Narratives', South African Historical Journal, 62, (3) $2010,444-462$.

Penn, N., 'Close and Merciful Watchfulness': The Origins and Nature of John Montagu's Convict System in the MidNineteenth Century Cape Colony', Cultural and Social History, 5, 4 (2008), 465 - 480.

Rayner, M., 'Wine and Slaves: The Failure of an Export Economy and the Ending of Slavery in the Cape Colony, South Africa, 1806 - 1834' (PhD thesis, Duke University, 1986).

Rediker, M., Between the Devil and the Deep Blue Sea (Cambridge: Cambridge University Press, 1987).

Roodeburg, H., ed., Forging European Identities, 1400 - 1700 (Cambridge: Cambridge University Press, 2007).

Roper, L., Oedipus and the Devil: Witchcraft, Sexuality and Religion in Early Modern Europe (London: Routledge, 1994).

Ross, R., Cape of Torments: Slavery and Resistance in South Africa (London: Routledge, 1983)

Ross, R., 'The Rise of the Cape Gentry', Journal of Southern African Studies, 9 (1983), 193 - 217.

Ross, R., Beyond the Pale: Essays on the History of Colonial South Africa (Johannesburg: Witwatersrand University Press, 1994).

Ross, R., Status and Respectability in the Cape Colony, 1750 - 1870 (Cambridge: Cambridge University Press, 1999). 
Ross, R., 'Khoesan and Immigrants: The Emergence of Colonial Society in the Cape, 1500 - 1800', in C. Hamilton, B. Mbenga and R. Ross, eds, The Cambridge History of South Africa, Vol. I (Cambridge: Cambridge University Press, 2010), $168-210$.

Rublack, U., Gender in Early Modern Germany (Cambridge: Cambridge University Press, 2002).

Schama, S., The Embarrassment of Riches: An Interpretation of Dutch Culture in the Golden Age (London: Collins, 1987).

Schoeman, K., Armosyn van die Kaap: Die Wêreld van 'n Slavin, 1652 - 1733 (Cape Town: Human and Rousseau, 2001).

Scully, P., Liberating the Family?: Gender and British Slave Emancipation in the Rural Western Cape, South Africa, 1823 - 1853 (Portsmouth, NH: Heinemann and Cape Town: David Philip, 1997).

Stuart, K., Defiled Trades and Social Outcasts: Honor and Ritual Pollution in Early Modern Germany (Cambridge: Cambridge University Press, 1999).

Taylor, N., 'A Scapegoat of Status on the Streets of $18^{\text {th }}$ Century Cape Town', Historical Approaches (Historical Studies Department, University of Cape Town), 4 (2007), $12-18$.

Ulrich, N., 'Dr Anders Sparrman: Travelling with the Labouring Poor in the Late Eighteenth-Century Cape', South African Historical Journal, 61, 4 (2009), 731 - 749.

Ulrich, N., 'Time, Space and the Political Economy of Merchant Capitalism in the Cape of Good Hope and VOC World', South African Historical Journal, 62, (3) 2010, 571 - 588.

Ulrich, N., 'Abolition from Below: The 1808 Revolt in the Cape Colony', in M. van der Linden, ed., 'Humanitarian Intervention' and Changing Labour Relations: Long-Term Consequences of the British Act on the Abolition of the Slave Trade, 1807 (Leiden and Boston: Brill, 2010), forthcoming.

Ward, K. Networks of Empire: Forced Migration in the Dutch East India Company (Cambridge: Cambridge University Press, 2009).

Wilson, K., The Island Race: Englishness, Empire and Gender in the Eighteenth Century (London and New York: Routledge, 2003).

Worden, N. and Crais, C., eds, Breaking the Chains: Slavery and its Legacy in the Nineteenth-Century Cape Colony (Johannesburg: Witwatersrand University Press, 1994).

Worden, N., 'Forging a Reputation: Artisan Honour and the Cape Town Blacksmith Strike of 1752', Kronos, 28 (2002), $43-65$.

Worden, N. and Groenewald, G., eds, Trials of Slavery: Selected Documents Concerning Slaves from the Criminal Records of the Council of Justice at the Cape of Good Hope, 1705 - 1794 (Cape Town: Van Riebeeck Society, 2005).

Worden, N., ed., Contingent Lives: Social Identity and Material Culture in the VOC World (Cape Town: Department of Historical Studies, University of Cape Town, 2007).

Worden, N., 'New Approaches to VOC History in South Africa', South African Historical Journal, 59 (2007), 3 - 18.

Worden, N., 'Strangers Ashore: Sailor Identity and Social Conflict in Mid-Eighteenth Century Cape Town', Kronos, 33 (2007), $72-83$.

Worden, N., 'Demanding Satisfaction: Violence, Masculinity and Honour in Late Eighteenth-Century Cape Town', Kronos, 35 (2009), $32-47$.

Worden, N., 'The Changing Politics of Slave Heritage in the Western Cape, South Africa', Journal of African History, 50 (2009), $23-40$.

Worden, N., "“Armed with Swords and Ostrich Feathers": Militarism and Cultural Revolution in the Cape Slave Uprising of 1808', in R. Bessel, N. Guyatt and J. Rendall, eds, War, Empire and Slavery, 1770 - 1830 (London: Palgrave, 2010), $121-138$. 